\title{
When Science and Politics Collide
}

\author{
Barbara Atkinson, MD \\ Executive Vice Chancellor \\ University of Kansas Medical Center
}

S

cience, at its essence, is the force inherent in our nature to better understand the world around us. The thirst to know more, to discover new knowledge, and to improve the quality of life are innate human characteristics, and yet science is also perceived by some as a threat. Throughout history, those who have sought the advancement of science to improve the human condition have often found others constructing speed bumps to progress, and some have succeeded in significantly slowing its pace. And so it is again today, as science and politics collide over issues surrounding stem cell research and therapeutic cloning.

As a physician, an educator, a researcher, and a leader in the health care community, I believe it is my responsibility and the responsibility of all scientists and educators to be a resource, both to the public and to lawmakers who have a responsibility to decide crucial issues such as this.

For that reason, I testified in March 2005 before the Kansas House Federal and State Affairs Committee against House Bill 2355. The critical problem that I and many others see with HB 2355 is that, while it aims to outlaw human cloning, the specific language of the bill does so at the expense of criminalizing the exploration of an entire category of research that holds the potential to profoundly ease human suffering-research that will allow us to study the molecular basis of diseases as they develop from conception to death. This research holds the promise of discovering treatments and cures for such chronic diseases as Parkinson's, juvenile diabetes, ALS, heart disease, cancer, spinal cord injuries and Alzheimer's disease.

Between April and October 2005, I gave 50 talks on the science of stem cell research to citizens throughout the state of Kansas. I also recently conducted a series of seminars with Kansas legislators called Stem Cell Research 101 to educate them on the science and ethical considerations of this work.

Much of the controversy and misunderstanding about stem cell research centers on use of the emotional and highly-charged word "cloning." When most of us hear this word out of context, we tend to think of the process of creating genetically identical human beings-human reproductive cloning-a terrifying prospect to be sure.

In fact, there is another type of cloning, called "therapeutic cloning," that seeks to create a line of stem cells genetically identical to the originating cell 
for use in research and treatment. One of the most promising forms of therapeutic cloning is called "somatic cell nuclear transfer" or SCNT for short. SCNT is the transplanting of a patient's DNA into an unfertilized egg in order to grow stem cells that could replace organs or tissue in order to cure diseases. They could also be used to discover new drugs for the treatment of patients.

SCNT is not meant to create new life; it literally extends life. SCNT works with the cells of an already-living person to create an environment where these cells can multiply to produce stem cells. These stem cells can then replace damaged cells in the body, such as bone marrow for leukemia and chemotherapy patients, nerve cells for Parkinson's and Alzheimer's disease patients, heart muscle cells for diseased hearts, and pancreatic islet cells for diabetic patients.

SCNT is also essential to help scientists understand how stem cells and other cells develop. This includes understanding how cancer cells grow and develop, which is essential for ultimately finding a cure for cancer.

The goal of therapeutic cloning or SCNT is not to produce babies. There is no fertilization of the egg by sperm, no implantation in the uterus and no pregnancy. The goal is to produce cells. SCNT's aim is to treat or cure patients by creating tailor-made, genetically identical stem cells that the patient's body will not reject after transplantation. SCNT could allow patients to be cured using their own DNA and could result in significant breakthroughs just as the use of stem cells in bone marrow transplants is saving lives today. Unfortunately, SCNT could be criminalized under the provisions of HB 2355.

At The University of Kansas Medical Center we are very supportive of efforts to utilize adult stem cells (stem cells drawn from fetal cord blood or from other adult tissue sources) for biomedical research. However, adult stem cells and early stem cells are not replacements for one another. Because early stem cells are pluripotent--meaning they can become any cell in the body--they can be applied to a far greater variety of contexts than adult stem cells and can also be grown in a lab indefinitely. Consequently, pursuing both avenues provides the best hope for achieving dramatic progress in discovering new cures.

I would like to point out that there are other unintended consequences to criminalizing SCNT. The spirit of discovery that fuels scientific advancement in our society would be lost. In addition, Kansas patients may be deprived of the benefits of currently accepted treatments and the science behind those treatments. And patients and perhaps physicians as well - may leave our medical centers and hospital to pursue the possibility of more innovative care provided in other states. If that occurs, there will be a direct economic impact and an indirect loss of additional business growth.

While the nation and our state are currently engaged in a robust discussion regarding the appropriate use of stem cell research, a large majority of Americans and Kansans believe such research has promise and should be pursued.

According to a WSJ/Harris Interactive Poll in June 2005, 74\% of Americans think that stem cell research 
should be allowed, 14\% believe it should not be allowed and $12 \%$ are not sure.

According to similar polls conducted in Kansas and Missouri, 61\% of Kansans and $56 \%$ of Missourians approve of stem cell research, while $21 \%$ and $24 \%$, respectively, disapprove. When asked if they approve or disapprove of SCNT research, $71 \%$ of Kansans and Missourian said they approved.

During the last Missouri legislative session, an anti-stem cell research bill was argued for in the Senate by Republicans but shelved for lack of support. It is anticipated that the bill will be reintroduced in 2006. Some are considering whether to have a public referendum for a constitutional amendment during the November 2006 election.

In Kansas, an anti-human cloning bill was introduced in the House and 49 representatives signed on. Hearings and discussion followed by the House Federal and State Affairs Committee; the chair did not report the bill out of committee and sent it for intersession review. It is expected that the bill will be reintroduced.

In response to restrictions on stem cell research, many Americans have become involved in advocating for research. We have an active group of committed individuals in the Greater Kansas City Chamber of Commerce who have made this the Chamber's top legislative agenda item.

A campaign being conduced by the Kansas Coalition for Life Saving Cures will reach many Kansans and encourage them in turn to advocate for research to improve the quality of life for those suffering from debilitating disease. The educational effort that will be at the cornerstone of this campaign will have tremendous collateral benefits. It is our opportunity to teach new audiences, to build new coalitions, and to advance our mission of improving human health through research.

This is a time of vigilance. We cannot afford to be complacent or silent. All of us share an obligation to advance the search for truth. As the line between science and politics grows thinner, it is our responsibility to be a principled resource for our policymakers, for our public, and for those who may benefit from these scientific endeavors.

I understand and appreciate the deep moral and ethical considerations involved with this issue, but I remain convinced that laws that would prevent and criminalize the pursuit of research to discover life saving cures and treatments are inappropriate. I applaud efforts to outlaw human reproductive cloning, as do all reputable researchers, but I urge our lawmakers to advance the cause of research, education and healthcare by opposing legislation that limits the lifesaving cures and treatments central to our shared mission and to the overall quality of life of Kansans.

Kansas has always been a state known for its sweeping horizons. It will be up to us to make Kansas a place that really is as big as you think. 